\title{
To Study Correlation and Path Analysis in Rice Breeding Lines
}

\author{
Sujeet Singh Kanwar and Yogesh Kumar Nag* \\ Department of Genetics and Plant Breeding, Indira Gandhi Krishi \\ Vishwavidyalaya, Raipur, India \\ *Corresponding author
}

\author{
A B S T R A C T
}

\begin{tabular}{|c|}
\hline Keywords \\
\hline $\begin{array}{l}\text { Breeding lines, } \\
\text { Coefficient of } \\
\text { variation, Path } \\
\text { analysis, } \\
\text { Heritability }\end{array}$ \\
\hline Article Info \\
\hline $\begin{array}{l}\text { Accepted: } \\
17 \text { November } 2019 \\
\text { Available Online: } \\
10 \text { December } 2019\end{array}$ \\
\hline
\end{tabular}

Keywords

Breeding lines, Coefficient of variation, Path analysis,

Heritability

\section{Introduction}

Rice is the most consumed cereal grain in the world, constituting the dietary staple food for more than half of the planet's human population. In Asian countries, rice is the main staple crop covering about ninety per cent of rice grown in the world, with two countries, China and India, growing more than half of the total crop. Rice provides about two-third of the calorie intake for more than two billion people in Asia, and a third of the calorie intake of nearly one billion people in Africa and
Latin America (Shastry et al., 2000). India is the second largest producer of rice after China has an area of over 43.77 million hectares with the production of 89.05 million tons in 2010 (Anonymous, 2011a). Rice being the main source of livelihood for more than 120-150 million rural household is the backbone of the Indian Agriculture. It occupies about 23.3 per cent of the food grain production and 55 percent of cereal production. The rice plays a very vital role in the national food security. Even then rice self-sufficiency in India is precarious. The country's population of more 
than a billion is growing at $1.8 \%$ per year, outpacing the $1.4 \%$ annual growth rate of rice production.

Chhattisgarh popularly known as "Rice Bowl of India" occupies an area around 3.61 million hectares with the production of 5.22 MT (Anonymous, 2011b). The prime causes of low productivity of rice in Chhattisgarh are unappropriate adoption of agronomical practices, limited irrigation $(28.0 \%)$ and lack of improved varieties suitable to different ecosystems.

Aromatic rice varieties are very much popular for their quality and aroma. Aroma quality of scented rice is major character, which increases the value of rice in the international market. In addition to long grain Basmati type which have high export potential, there are large number of indigenous short grained aromatic varieties cultivated in pockets of different states. Despite of low yield, they posses valuable genes for aroma, excellent cooking and eating quality traits and enjoy immense consumer preference in Chhattisgarh and in many other states. Grain quality in rice is a combination of many physico-chemical traits (Juliano, 1970). Physical quality is determined by the grain dimension, hulling, milling and head rice recovery. The quality of starch gelatinization temperature and protein content mainly constitute the chemical quality of rice. The cooking qualities are indexed by alkali spreading value, cooked kernel length, and elongation ratio. Scented varieties in general are tall, photoperiod sensitive with low yield potential. Therefore, presently much emphasis is given by the researchers on the development of high yielding varieties with good grain quality and aroma.

\section{Materials and Methods}

The present research study on "Analysis of genetic variability for yield and quality characters in aromatic advanced breeding lines of rice (Oryza sativa L.)" was conducted at Research Farm, Department of Genetics and Plant Breeding, College of Agriculture, Indira Gandhi Krishi Vishwavidyalaya, Raipur, Chhattisgarh, India.

\section{Experimental material}

The experimental material was consisting of ninety eight aromatic advanced breeding lines of rice along with popular standard checks viz., Indira Sugandhit Dhan-1, Pusa Basmati1, Badsha Bhog, Dubraj, Chinnor, Mahisugandha, and Kalanamak, These breeding lines were received from rice section of department of Genetics and Plant Breeding I.G.K.V Raipur (C.G.)

\section{Methods}

The experiment was conducted to evaluate the ninety eight aromatic advanced breeding lines of rice along with popular standard checks in a randomized block design with two replications. Each breeding line was grown in a plot comprising 7 rows of 5 meter long maintaining inter and intra row spacing of $20 X 15 \mathrm{~cm}$. Transplanting of the material was done manually when the seedlings were 21 days old nursery.

\section{Results and Discussion}

The correlation coefficients analysis is the index of association between two variables. These have been dealt in all possible combinations for important characters at phenotypic, genotypic and environmental level and are presented in table 1.

The characters days to $50 \%$ flowering had a highly significant positive correlation with filled spikelets per panicle, unfilled spikelets per panicle and total spikelets per panicle at phenotypic and genotypic level. It also 
showed highly significant negative correlation with 100- seed weight at phenotypic and genotypic level.

The character plant height recorded the highly significant positive correlation with panicle length at phenotypic and genotypic level. It showed highly significant negative correlation with filled spikelets per panicle at genotypic level. Filled spikelets per panicle showed significant negative correlation at phenotypic level only.

Panicle length recorded the non significant positive and negative relationship with all characters at phenotypic, genotypic and environmental levels.

Total number of tillers per plant showing the highly significant positive correlation with number of effective tillers per plant at phenotypic, genotypic and environmental level and with grain yield per plant at environmental level only. It also showed highly significant positive correlation with number of spikelets sterility percentage at genotypic level.

Number of effective tillers per plant is showing the highly significant positive association with grain yield per plant at environmental level only.

The character number of total spikelet per panicle expressed highly significant positive correlation with filled spikelets per panicle and unfilled spikelets per panicle at phenotypic, genotypic and environmental level, whereas it showed highly significant negative correlation with 100- seed weight at phenotypic, genotypic and environmental level. Grain yield per plant showed highly significant positive correlation at phenotypic and genotypic level only with this trait.

Filled spikelet per panicle is showing the highly positive correlation with Grain yield per plant at phenotypic and genotypic level. It showed highly significant positive correlation with 100- seed weight at phenotypic and environmental level only.

Unfilled spikelets per panicle showed highly significant positive association with spikelet sterility percentage at phenotypic, genotypic and environmental level, while it showed highly significant negative correlation with 100- seed weight at genotypic and environmental level. While it showed significant negative correlation with grain yield per plant at genotypic level only. The other character showing non- significant positive or negative association with this trait.

The character spikelet sterility percentage had a highly significant negative correlation with 100 - seed weight and grain yield per plant at phenotypic and genotypic level only.

The character 100-seed weight showed the highly significant positive correlation with grain yield per plant at phenotypic, genotypic and environmental level.

The character grain yield per plant showing highly significant positive correlation with 100-seed weight at phenotypic, genotypic and environmental level, number of total effective tillers per plant at environmental level. On the other hand unfilled spikelet per panicle is showing significant negative correlation at genotypic level. It had shown highly significant positive correlation with filled spikelets per panicle at phenotypic and genotypic level, number of total spikelet's per panicle at phenotypic and genotypic level, while, it showed highly significant negative correlation with spikelets sterility percentage at phenotypic and genotypic level only.

In the present investigation grain yield per plant was positively and significantly associated with 100-seed weight, number of total effective tillers per plant, filled spikelets 
per panicle and total spikelets per panicle. The positive association of grain yield per plant with filled spikelet per panicle is in similar to the finding of Surek and Beser (2003) and Sourosh et al., (2004), Veni and Rani (2006), Nath et al., (2008). Grain yield per plant was positively and highly significant associated with total spikelets per panicle which is in conformity to the findings of Shashidhar et al., (2005), Kumar (2008), Chakraborty and Chakraborty (2010). The positive association of Grain yield per plant with number of effective tillers per plant is in conformation with the findings of Patil and Sarawgi (2005), Monalisa et al., (2006), Johnson et al., (2007), Kumar (2008). The positive association of Grain yield per plant with 100-seed weight is similar to finding of Nath et al., (2008), Subudhi and Dikshit (2009) and Chandra et al., (2009).

The path coefficient analysis was carried out by using the correlation coefficient between different quantitative characters to obtain direct and indirect effects of different characters on grain yield per plant. The direct and indirect effects of different characters on grain yield per plant are presented in table 2 .

The path analysis discerns correlation into direct and indirect effects. The present investigation was under taken to establish the relation between component characters. Days to $50 \%$ flowering and plant height had a negligible negative direct effect on grain yield per plant. It had also shown a negative correlation with seed yield per plant. Panicle length showed a low positive direct effect on grain yield per plant. Effective tillers per plant expressed a high positive direct effect on grain yield per plant. Total spikelets showed very high positive direct effect on grain yield per plant. This indicates a true relationship. Unfilled spikelets per panicle showed a high negative direct effect on grain yield per plant, it had also highly significant negative association with grain yield per plant. Filled grain showed a negligible negative direct effect on grain yield per plant, but it shows significant positive association with grain yield per plant. This positive association may be due to very high positive indirect effect via total number of spikelets.

Table.1 Genotypic path showing direct and indirect effect on grain yield

\begin{tabular}{|c|c|c|c|c|c|c|c|c|c|c|c|}
\hline Characters & DF & PH & PL & TT/P & ET/P & TS/Pa & FG/Pa & UG/Pa & SSP & SI & $\begin{array}{c}\text { Correlation } \\
\text { coefficient GY/P }\end{array}$ \\
\hline & 1 & 2 & 3 & 4 & 5 & 6 & 7 & 8 & 9 & 10 & 11 \\
\hline DF & $\mathbf{- 0 . 0 8 1}$ & -0.006 & 0.005 & 0.004 & 0.035 & -0.447 & 0.768 & -0.161 & 0.216 & -0.373 & -0.062 \\
\hline PH & -0.009 & $\mathbf{- 0 . 0 5 6}$ & 0.069 & 0.054 & -0.037 & 0.233 & -0.595 & -0.012 & 0.179 & 0.031 & -0.172 \\
\hline PL & -0.003 & -0.024 & $\mathbf{0 . 1 6 1}$ & 0.016 & -0.040 & 0.211 & -0.523 & -0.003 & 0.142 & 0.020 & -0.050 \\
\hline TT/P & -0.001 & -0.010 & 0.008 & $\mathbf{0 . 3 0 4}$ & -0.102 & 0.122 & -0.468 & -0.083 & 0.262 & -0.265 & -0.230 \\
\hline ET/P & 0.016 & -0.012 & 0.038 & 0.181 & $\mathbf{- 0 . 1 7 1}$ & 0.160 & -0.357 & 0.018 & 0.053 & -0.132 & -0.154 \\
\hline TS/Pa & -0.038 & 0.014 & -0.035 & -0.039 & 0.029 & $\mathbf{1 . 9 5 8}$ & -0.195 & -0.959 & 0.070 & -0.408 & $0.398^{* *}$ \\
\hline FG/Pa & -0.030 & 0.016 & -0.041 & -0.069 & 0.029 & 2.067 & $\mathbf{- 0 . 0 7 9}$ & -0.908 & -0.205 & -0.233 & $0.557 * *$ \\
\hline UG/Pa & -0.034 & -0.002 & 0.001 & 0.066 & 0.008 & 0.431 & -0.380 & $\mathbf{- 0 . 4 9 1}$ & 0.763 & -0.617 & $0.398^{* *}$ \\
\hline SSP & -0.020 & -0.012 & 0.026 & 0.093 & -0.010 & -0.078 & -0.492 & -0.336 & $\mathbf{0 . 8 6 1}$ & -0.531 & $-0.528^{* *}$ \\
\hline SI & 0.034 & -0.002 & 0.004 & -0.090 & 0.025 & 0.438 & -0.540 & 0.262 & -0.512 & $\mathbf{0 . 8 9 4}$ & $0.521 * *$ \\
\hline Resi & & & & & & & & \\
\hline
\end{tabular}

Residual effect -: 0.1296

1. DF: Days to 50\% flowering; 2. PH: Plant Height; 3. PL: Panicle length; 4. TT/P: Total tiller per plant; 5.ET/P: Effective tiller per plant; 6. TS/Pa: Total spikelets per panicle; 7. FG/Pa: Filled spikelets per panicle; 8. UG/Pa: Unfilled spikelets per panicle; 9. SSP: Spikelet sterility percentage; 10. SI: 100 seed weight; 11. GY/P: Grain yield per plant.

*The bold data are the direct effect over grain yield. 
Table.2 Phenotypic (P), Genotypic (G), and Environmental (E) Correlation coefficient for quantitative traits

\begin{tabular}{|c|c|c|c|c|c|c|c|c|c|c|c|c|}
\hline S.N. & & DF & $\mathrm{PH}$ & PL & $\mathrm{TT} / \mathrm{P}$ & ET/P & $\mathrm{TS} / \mathrm{Pa}$ & $\mathrm{FG} / \mathrm{Pa}$ & $\mathrm{UG} / \mathrm{Pa}$ & SSP & SI & GY/P \\
\hline & & 1 & 2 & 3 & 4 & 5 & 6 & 7 & 8 & 9 & 10 & 11 \\
\hline \multirow[t]{3}{*}{1} & $\mathrm{P}$ & 1.000 & 0.109 & 0.016 & 0.001 & -0.155 & $0.428 * *$ & $0.342 * *$ & $0.382 * *$ & 0.223 & $-0.337 * *$ & -0.051 \\
\hline & G & 1.000 & 0.155 & 0.033 & 0.015 & -0.203 & $0.466 * *$ & $0.371 * *$ & $0.425^{* * *}$ & 0.251 & $-0.418^{* *}$ & -0.062 \\
\hline & E & 1.000 & -0.054 & -0.203 & -0.137 & -0.018 & 0.053 & 0.066 & -0.014 & -0.046 & -0.081 & 0.012 \\
\hline \multirow[t]{3}{*}{2} & $\mathrm{P}$ & & 1.000 & $0.374 * *$ & 0.142 & 0.175 & -0.233 & $-0.272 *$ & 0.017 & 0.176 & 0.048 & -0.134 \\
\hline & G & & 1.000 & $0.429 * *$ & 0.177 & 0.214 & -0.243 & $-0.288 * *$ & 0.031 & 0.208 & 0.035 & -0.172 \\
\hline & E & & 1.000 & 0.108 & 0.035 & 0.108 & -0.176 & -0.157 & -0.107 & -0.069 & 0.146 & 0.051 \\
\hline \multirow[t]{3}{*}{3} & $\mathrm{P}$ & & & 1.000 & 0.086 & 0.179 & -0.164 & -0.194 & 0.020 & 0.138 & -0.003 & -0.020 \\
\hline & G & & & 1.000 & 0.053 & 0.234 & -0.220 & -0.253 & 0.007 & 0.164 & 0.022 & -0.050 \\
\hline & E & & & 1.000 & 0.164 & 0.078 & 0.060 & 0.041 & 0.067 & 0.044 & -0.059 & 0.064 \\
\hline \multirow[t]{3}{*}{4} & $\mathrm{P}$ & & & & 1.000 & $0.550 * *$ & -0.074 & -0.139 & 0.146 & 0.205 & -0.164 & -0.063 \\
\hline & G & & & & 1.000 & $0.596 * *$ & -0.127 & -0.226 & 0.218 & 0.304** & -0.297 & -0.230 \\
\hline & E & & & & 1.000 & $0.481 * *$ & 0.081 & 0.110 & -0.044 & -0.053 & 0.067 & $0.279 *$ \\
\hline \multirow[t]{3}{*}{5} & $\mathrm{P}$ & & & & & 1.000 & -0.079 & -0.098 & 0.021 & 0.084 & -0.083 & 0.063 \\
\hline & G & & & & & 1.000 & -0.167 & -0.173 & -0.047 & 0.061 & -0.147 & -0.154 \\
\hline & E & & & & & 1.000 & 0.149 & 0.091 & 0.194 & 0.152 & 0.015 & $0.461^{* * *}$ \\
\hline \multirow[t]{3}{*}{6} & $\mathrm{P}$ & & & & & & 1.000 & $0.945 * *$ & $0.510 * *$ & 0.080 & $-0.485 * *$ & $0.320 * *$ \\
\hline & G & & & & & & 1.000 & $0.947 * *$ & $0.512 * *$ & 0.082 & $-0.4566^{* *}$ & $0.398 * *$ \\
\hline & E & & & & & & 1.000 & $0.936 * *$ & $0.504 * *$ & 0.074 & $-0.636 * *$ & 0.059 \\
\hline \multirow[t]{3}{*}{7} & $\mathrm{P}$ & & & & & & & 1.000 & 0.202 & 0.244 & $\mathbf{0 . 3 3 0}^{* *}$ & $0.458 * *$ \\
\hline & G & & & & & & & 1.000 & 0.209 & -0.238 & 0.261 & $0.557 * *$ \\
\hline & E & & & & & & & 1.000 & 0.167 & -0.276 & $0.587 * *$ & $\mathbf{0 . 1 2 7}$ \\
\hline \multirow[t]{3}{*}{8} & $\mathrm{P}$ & & & & & & & & 1.000 & $0.885 * *$ & $0.586 * *$ & -0.246 \\
\hline & G & & & & & & & & 1.000 & $0.885 * *$ & $-0.691 * *$ & $-0.279 *$ \\
\hline & E & & & & & & & & 1.000 & $0.885 * *$ & $-0.339 * *$ & -0.146 \\
\hline \multirow[t]{3}{*}{9} & $\mathrm{P}$ & & & & & & & & & 1.000 & $-0.441^{* *}$ & $-0.446 * *$ \\
\hline & G & & & & & & & & & 1.000 & $-0.594 * *$ & $-0.528 * *$ \\
\hline & E & & & & & & & & & 1.000 & -0.045 & -0.189 \\
\hline \multirow[t]{3}{*}{10} & P & & & & & & & & & & 1.000 & $0.486 * *$ \\
\hline & G & & & & & & & & & & 1.000 & $0.521^{* *}$ \\
\hline & E & & & & & & & & & & 1.000 & $0.418 * *$ \\
\hline \multirow[t]{3}{*}{11} & $\mathrm{P}$ & & & & & & & & & & & 1.000 \\
\hline & G & & & & & & & & & & & 1.000 \\
\hline & E & & & & & & & & & & & 1.000 \\
\hline
\end{tabular}

*Significant at $1 \%$ level $\quad * *$ Significant at $5 \%$ level

Note: 1. DF: Days to 50\% flowering; 2. PH: Plant Height, 3. PL: Panicle length; 4. TT/P: Total tiller per plant;

5.ET/P: Effective tiller per plant; 6. TS/Pa: Total spikelets per panicle; 7. FG/Pa: Filled spikelets per panicle;

8. UG/Pa: Unfilled spikelets per panicle; 9. SSP: Spikelet sterility percentage; 10. SI: 100 seed weight;

11. GY/P: Grain yield per plant.

Spikelet sterility percentage had high positive direct effect on grain yield per plant, but it had significant positive correlation with grain yield per plant. This negative association may be due to high negative indirect effect via filled spikelets per panicle, unfilled spikelets per panicle and 100-seed weight on seed yield per plant. 100-seed weight had high positive direct effect on grain yield per plant. It had also shown significant positive association with grain yield per plant.

The positive direct effect of panicle length on grain yield per plant in present study was similer to the findings of Iftekharuddaula et al., (2002), Anurag et al., (2006) and Kumar (2008). Spikelet sterility percentage had high positive direct effect on grain yield per plant 
is in accordance with the findings of Khedikar et al., (2004) and Johnson et al., (2007).

100-seed weight showed high positive direct effects on grain yield per plant Similar finding have also been reported by Iftekkharuddaula et al., (2002) and Chandra et al., (2009).

On the basis of above finding it can be concluded that the direct selection for characters viz. 100- seed weight will be very effective for increasing the grain yield whereas, it is logical to select the plants having less spikelet sterility for improvement in grain yield however the character viz. days to $50 \%$ flowering, effective tiller per plant and filled spikelets per panicle also expressed considerable indirect effects through one or more characters on grain yield per plant, hence they should be given consideration in selection criteria.

The correlation coefficients analysis is the index of association between two variables. These have been dealt in all possible combinations for important characters at different level. In the present investigation Grain yield per plant was positively and significantly associated with 100 -seed weight, Number of total effective tillers per plant, Filled spikelets per panicle and Total spikelets per panicle. The path coefficient analysis was carried out by using the correlation coefficient between characters to obtain direct and indirect effects on grain yield per plant. Number of total tiller per plant, Total number of Spikelets per panicle, Spikelet sterility percentage and 100 seed weight had high positive direct effect on Grain yield per plant.

\section{References}

Anonymous, 2011a. The Hindu Survey of Indian Agriculture. Agril. Statistics Division Directorate of Economics \& Statistics Dept. of Agriculture and corporation, p. 125.

Anonymous, 2011b. Credible Chhattisgarh, Raipur. p. 8.

Anurag, Bhandarkar, S. and Pandagare, J.M. 2006. Correlation and path analysis in pure lines of rice under rainfed condition of Bastar plateau zone of Chhattisgarh. In: Lakpale, R. (ed.) Agro Resource conservation and management. IGKV, Raipur, p. 159.

Chakraborty, R. and Chakraborty, S. 2010. Genetic variability and correlation of some morphometric traits with grain yield in bold grained rice (Oryza sativa L.). Gene Pool of Barak Valley American-Eurasian J. of Sustainable Agriculture, 4(1): 26-29.

Chandra, B.S., Reddy, T.D., Ansari, N.A. and Kumar, S.S. 2009.Correlation and path analysis for yield and yield components in rice (Oryza sativa L.). Agricultural Science Digest, 29(1): 214-315.

Iftekkharuddula, K.M., Akhtar, K., Hassan, M.S., Fatema, K. and Badshah, A. 2002. Genetic divergence, character association and selection criteria in irrigated rice. J. Biol. Sci., 2(4): 243246.

Johnson, P.L., Sarawgi, A.K. and Verma, R.K. 2007. Correlation coefficient and path analysis for quantitative characters under rainfed lowland rice. J. Agril. Issues, 12(1): 46-51.

Juliano, B.O. 1970. Relation of physicchemical properties to properties characteristics of rice. Proc. $5^{\text {th }}$ Central and Board Congress, 4: 21-27.

Khedikar, V.P., Bharose, A.A., Sharma, D., Khedikar, Y.P. and Khillare, A.S. 2004. Path coefficient analysis of yield components of scented rice. J. Soils Crops, 14(1): 198-201.

Kumar, P. 2008. Combining ability analysis and heterosis for grain yield and its related characters in rice. M.Sc.(Ag.) Thesis, Indira Gandhi Krishi 
Vishwavidyalaya, Raipur, 135-136.

Monalisa, M., Ali, M.N. and Sasmal, B.G. 2006. Variability, correlation and path coefficient analysis in some important traits of lowland rice. Crop Research Hisar, 31(1): 153-156.

Nath, Shiva, Vishwakarma, D.N. and Chouhan, M.P. 2008. Association study in yield and yield components traits in hybrid rice (Oryza sativa L.) under stress and saline/sodic condition. Agric. Sci. Digest, 28(1): 73-74.

Patil, P.V., and Sarawgi, A.K. 2005. Character association and component analysis in aromatic rice accessions from Chhattisgarh and Madhya Pradesh. PKV Res. J., 29(1): 59-65.

Shashidhar, H.E., Pasha, F., Janamatti, M., Vinod, M.S. and Kanbar, 2005. Correlation and path coefficient analysis in traditional cultivar and doubled haploid lines of rainfed lowland rice (Oryza sativa L.). Oryza, 42: 156-158.

Shastry, S.V., Tran, D.V., Nguyen, V.N. and Nanda, J.S. 2000. Sustainable integrated rice production. In: Nanda, J.S. (Ed) Rice Breeding and Genetics: Research Priorities and Challenges. Oxford and IBH Pub., New Delhi. pp. 53-72.

Sourosh, H.R., Mesbah, M., Hossainzadeh, A. and Bozorgipour, R. 2004. Genetic and phenotypic variability and cluster analysis for quantitative and qualitative traits of rice. Seed Plant, 20(2): 167182.

Subudhi, H.N. and Dikshit, N. 2009. Variability and character association of yield components in rain fed lowland rice. Indian J. Plant Genetic Resources, 22(1): 271-274.

Surek, Halil and Beser, Necmi. 2003. Correlation and path coefficient analysis for some yield-related traits in rice (Oryza sativa L.) under thrace condition. Turk J. Agric., 27: 77-83.

Veni, B.K. and Rani, N.S. 2006. Association of grain yield with quality characteristics and other yield components in rice. Oryza, 43: 320-322.

\section{How to cite this article:}

Sujeet Singh Kanwar and Yogesh Kumar Nag. 2019. To Study Correlation and Path Analysis in Rice Breeding Lines. Int.J.Curr.Microbiol.App.Sci. 8(12): 2481-2487. doi: https://doi.org/10.20546/ijcmas.2019.812.292 